\title{
COVID-19 PANDEMIC AND ENDANGERED LANGUAGES
}

\author{
Maya Khemlani David \\ Asia Europe Institute, University of Malaya, Malaysia \\ Prasannanshu \\ National Law University, Delhi, India
}

This Special Issue of IARS International Research Journal contains eight articles which investigate diverse aspects of Endangered Languages and COVID-19. The ongoing Covid-19 pandemic has redefined the way we live, work, and think. Consequently, it has become necessary for leaders, specialists, scholars, and academics of various fields to re-examine their positions and research objectives and methodologies in the context of this pandemic. The field of endangered languages is no different: It was soon realised that the effect of the pandemic on endangered languages is far reaching.

In many countries, government and nongovernment institutions and agencies have attempted to make information about the virus available in minority languages. Sebastian Drude (2020) in a Foundation of Endangered languages blog reports on the effort of Pakistani social activist Zubair Torwali, who worked with the provincial government of Khyber Pakhtunkhwa, to produce a series of information videos in a number of local languages and also of Malaysian Rusaslina Idrus who has co-ordinated teams of translators, medical specialists and native speakers to make Covid-19 information posters available in a number of Malaysian indigenous languages.

About twenty specialists representing several countries participated in a webinar on Covid-19 Pandemic, and Endangered Languages on July 910, 2020. This was organized by the UGC funded
Project on 'Study and Research towards Preservation and Promotion of Indigenous and Endangered Languages in collaboration with the Centre for Linguistic Justice and Endangered Languages, at the National Law University Delhi.

These specialists came together to share, learn from each other and to discuss approaches and policies for using and activating minority languages to transmit information on the Virus to these minority communities.

The specialists included Sociolinguists, Language Teachers, Legal Scholars, Researchers of Endangered Languages and Statisticians.

The research articles in this volume include writers from Bangladesh, India, Indonesia, Malaysia, and Pakistan, who write about their respective strategies to counter challenges encountered by minority communities and their endangered languages. during these challenging times. Although limited in its geographical scope the articles offer breadth in terms of the possibilities discussed to find solutions to these challenges.

Languages that are endangered are typically the languages of the marginalised people - that is, communities that are struggling for their survival. It is important to explore the effects of desperation and economic problems on endangered languages.

In India the Society for Endangered and Lesser Known Languages launched an initiative headed by

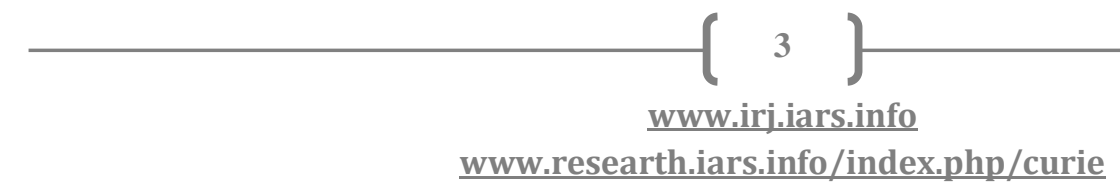


Kavita Rastogi (University of Lucknow) to coordinate efforts by volunteers to translate Covid-19 languages and Rastogi in this volume discusses how the Raji speech community was informed in their language, of precautions that had to be taken during the pandemic.

\section{Muhammad Hassan Abbasi and Maya Khemlani}

David focussing on Pakistan explain how medical health professionals, language activists and educationists use posters and social media to create awareness in local languages about the precautionary measures which have been taken to fight the pandemic among their indigenous minority speech communities.

In his study of the Manipuri language in the Sylhet area of Bangladesh Snehangshu Shekhar Chanda provides an optimistic picture of the active use of the language as he demonstrates that the language has been used more intensely during the pandemic and the ensuing lockdown. The writer explains that this is due to the increased use of social media.

Arun Kumar Singh, using both primary and secondary sources, explains the laws relating to the protection of endangered languages in India with a special focus on the state of Meghalaya while a researcher from the department of information technology Deepak Sharma, uses statistics to detect early factors like pandemics and other disasters which lead to language endangerment. $\mathrm{He}$ builds a model which has "significant predictive factor" for language endangerment.

The segmental phonology of Maithili Urdu spoken in the northern districts of Bihar, India, is described in detail by M. J. Warsi as it is believed that such lesser known languages are found to be especially vulnerable in times of crisis.

In a study focussing on the multilingual city of Denpasar in Bali I Made Suastra, Luh Putu Laksminy and Gede Primahadi Wijaya Rajeg explain how and why the Balinese language is not acquired as a mother tongue in this city. Such research-based data will hopefully give insights and shed light on ways for preserving such languages

In the final paper Udaya Narayana Singh discusses the research and action that should be taken by what he terms "responsible sociolinguists" and provides a list of tasks to be undertaken by such linguists. He argues that in resolving language endangerment in a post-Covid world, speech communities "...must be helped to learn the ways of tackling such situations."

This introduction to this Special Issue is deliberately kept brief in the hope that readers will focus their attention on the diverse ways in which the writers, given their respective disciplines, be it as sociolinguists, lawyers, phoneticians and statisticians, discuss the wide range of ways they help endangered language communities in the face of COVID-19. 